Table 1. Therapeutic Suggested Approaches for COVID-19 and Possible Risk Factors for Mycobacterial Diseases

\begin{tabular}{|c|c|c|c|c|}
\hline Therapeutic Agent & $\begin{array}{l}\text { Pharmacological } \\
\text { Class }\end{array}$ & Proposed Mechanism of Action in COVID-19 & $\begin{array}{l}\text { Risk Factors for Mycobacterial } \\
\text { Disease }\end{array}$ & Reference \\
\hline Azithromycin & Antibiotic & Immunomodulatory properties and in vitro antiviral activity & $\begin{array}{l}\text { Potential emergence of macrolide- } \\
\text { resistant NTM }\end{array}$ & 9 \\
\hline Hydroxychloroquine & Antirheumatic & Anti-inflammatory action and preventing viral entry into the cell & Increased risk of NTM disease & 7 \\
\hline Remdesivir & Antiviral & Inhibition of RdRp, preventing viral RNA synthesis & $\begin{array}{l}\text { Drug-drug interaction with } \\
\text { rifampicin }\end{array}$ & 6 \\
\hline Lopinavir & Antiviral & Protease inhibitory activity, preventing viral replication & $\begin{array}{l}\text { Drug-drug interaction with } \\
\text { rifampicin }\end{array}$ & 6 \\
\hline Ritonavir & Antiviral & Protease inhibitory activity, preventing viral replication & $\begin{array}{l}\text { Drug-drug interaction with } \\
\text { rifampicin }\end{array}$ & 6 \\
\hline Dexamethasone & Corticosteroid & $\begin{array}{l}\text { Anti-inflammatory and immunosuppressive properties, } \\
\text { preventing cytokine storm and damage to lung tissue }\end{array}$ & $\begin{array}{l}\text { Drug-drug interaction with } \\
\text { rifampicin }\end{array}$ & 5 \\
\hline Anakinra & Immunomodulator & $\begin{array}{l}\text { Blocking IL-1 signaling, preventing cytokine storm and damage } \\
\text { to lung tissue }\end{array}$ & Reactivation of latent TB & 8 \\
\hline Canakinumab & Immunomodulator & $\begin{array}{l}\text { Blocking IL-1 signaling, preventing cytokine storm and damage } \\
\text { to lung tissue }\end{array}$ & Reactivation of latent TB & 8 \\
\hline Tocilizumab & Immunomodulator & $\begin{array}{l}\text { Blocking IL-6 signaling, preventing cytokine storm and damage } \\
\text { to lung tissue }\end{array}$ & $\begin{array}{l}\text { Increased risk of NTM disease and } \\
\text { reactivation of latent TB }\end{array}$ & 8 \\
\hline Ruxolitinib & Immunomodulator & $\begin{array}{l}\text { JAK1 and JAK2 inhibition, preventing cytokine storm and } \\
\text { damage to lung tissue }\end{array}$ & $\begin{array}{l}\text { Increased risk of NTM disease and } \\
\text { reactivation of latent TB }\end{array}$ & 8 \\
\hline
\end{tabular}

Note. NTM, non-tuberculous mycobacteria; TB, tuberculosis; RdRp, RNA-dependent RNA polymerase; IL, interleukin; JAK, Janus kinases.

\section{References}

1. Weekly operational update on COVID-19-1 March 2021. World Health Organization website. https://www.who.int/publications/m/item/weeklyoperational-update-on-covid-19-1-march-2021. Updated March 1, 2021. Accessed March 3, 2021.

2. Magro, G. COVID-19: review on latest available drugs and therapies against SARS-CoV-2. Coagulation and inflammation cross-talking. Virus Res 2020, doi: 10.1016/j.virusres.2020.198070.

3. Crisan-Dabija R, Grigorescu C, Pavel CA, et al. Tuberculosis and COVID-19: lessons from the past viral outbreaks and possible future outcomes. Can Respire J 2020. doi: 10.1155/2020/1401053.

4. Rodriguez JA, Bonnano C, Khatiwada P, Roa AA, Mayer D, Eckardt PA. COVID-19 coinfection with Mycobacterium abscessus in a patient with multiple myeloma. Case Rep Infect Dis 2021. doi: 10.1155/2021/8840536.

5. Abdullah HN, Nowalid WKWM. Abnormal dexamethasone suppression tests in a rifampicin-treated patient with suspected Cushing's syndrome. Endokrynol Pol 2010;61:706-709.
6. Lemaitre F, Solas C, Grégoire M, et al. Potential drug-drug interactions associated with drugs currently proposed for COVID-19 treatment in patients receiving other treatments. Fundam Clin Pharmacol 2020; 34:530-547.

7. Brode SK, Jamieson FB, Ng R, et al. Increased risk of mycobacterial infections associated with anti-rheumatic medications. Thorax 2015;70: 677-682.

8. Kordzadeh-Kermani E, Khalili H, Karimzadeh I, Salehi M. Prevention strategies to minimize the infection risk associated with biologic and targeted immunomodulators. Infect Drug Resist 2020;13:513.

9. Choi H, Kim SY, Lee H, et al. Clinical characteristics and treatment outcomes of patients with macrolide-resistant Mycobacterium massiliense lung disease. Antimicrob Agents Chemother 2017;61(2):e02189-16.

10. Tan T, Khoo B, Mills EG, et al. Cortisol concentrations and mortality from COVID-19-authors' reply. Lancet Diabetes Endocrinol 2020;8: 809-810.

\title{
Implications of social distancing in Brazil in the COVID-19 pandemic
}

\author{
Raquel Cristina Cavalcanti Dantas $\mathrm{PhD}^{1}$ (1), Paola Amaral de Campos $\mathrm{PhD}^{2}$, Iara Rossi $\mathrm{MSc}^{2}$ and \\ Rosineide Marques Ribas PhD $^{2}$ \\ ${ }^{1}$ Institute of Biotechnology, Federal University of Uberlandia, Brazil and ${ }^{2}$ Laboratory of Molecular Microbiology, Federal University of Uberlandia, Brazil
}

Author for correspondence: Rosineide Marques Ribas, E-mail: rosi_ribas@yahoo. com.br

Cite this article: Dantas RCC, et al. (2020). Implications of social distancing in Brazil in the COVID-19 pandemic. Infection Control \& Hospital Epidemiology, 43: 953-954, https:// doi.org/10.1017/ice.2020.210
To the Editor-The pandemic caused by a novel coronavirus disease, known as COVID-19, carried millions of people around the world to a state of unprecedented panic. The World Health Organization (WHO) stated that more than one-third of the world is currently under some social distancing pattern, which is the 
oldest and probably one of the most effective methods for controlling infectious disease outbreaks. However, governments of many countries have difficulty implementing social distancing, particularly in developing countries such as Brazil, where income inequality is high and the national economy is fragile.

Several studies in the literature, both in developed and developing countries, have demonstrated the effectiveness of social distancing in slowing the spread of COVID-19., In a recent study, Taghrir et $\mathrm{al}^{1}$ investigated the efficacy of mass quarantine during the pandemic and found good-quality evidence for the social distancing strategies to have been highly effective in controlling the spread of the disease. Complementing this analysis, other researchers analyzed data of 8 countries extremely affected by COVID-19: China, Italy, Iran, Germany, France, Spain, South Korea, and Japan. They concluded that the rapidly increasing COVID-19 case numbers in European countries occurs due to late contention measures ${ }^{2}$. Therefore, social distancing is currently the most effective way to slow the spread of COVID-19.

In Brazil, the Ministry of Health recommended measures of social distancing, respiratory etiquette, and hand hygiene. ${ }^{3}$ Social distancing measures included the closing of schools, universities, and almost all shops, except food stores and pharmacies. In addition, cafes, restaurants, clubs, gyms, museums, and other institutions across the country have closed. Public gatherings, religious services, and social and sporting events have been cancelled. Nonetheless, the number of cases for COVID-19 has continued to grow exponentially due to difficulties in establishing true and effective social distancing. In the real Brazilian context, a large number of informal workers are still working normally and there is a lack of access to information for a large part of the population regarding minimum infection prevention and control measures, including hand washing and respiratory etiquette.

Although handwashing and social distancing are still the best measures to protect against the virus, the flattening the COVID19 curve will require additional measures in developing countries, where the spreading factor of the virus are different and more complex. In Brazil, it is essential to better understand the true prevalence of COVID-19, but the lack of mass testing is one of the main problems that make it difficult to implement measures to ensure that infected individuals are in an appropriate quarantine. Here, the physical distancing between infected and people is crucial in the high-risk group, such as the elderly and those with respiratory or chronic illnesses, to reduce the lethal effect of the pandemic.

According to the $\mathrm{WHO}$, wearing a surgical mask, in combination with hand hygiene and other preventative measures, is one of the prevention measures to limit the spread of SARS-CoV-2 in affected areas. ${ }^{4}$ Cowling et $\mathrm{al}^{5}$ demonstrated that the implementation of social distancing measures and changes in population behaviors, including use of facial masks, were associated with reduced transmission of SARS-CoV-2 in Hong Kong. In Brazil, the adoption of this equipment can be difficult due to the low adhesion or the lack of access to facial masks by the Brazilian population. Thus, the correct use of facial masks is fundamental to the effectiveness of the measure and can be encouraged and improved through education campaigns.

In Brazil, coronavirus is advancing exponentially. Although the disease has spread rapidly in large capitals, where the incidence of cases is high, COVID-19 cases are increasing in smaller cities and poorer communities as well. More than three-quarters of the confirmed cases are in southern and southeastern regions of Brazil, which are more densely populated, including many elderly, and with tropical and subtropical climates. In addition, the economic burden that sustained distancing can impose is potentially catastrophic in Brazil and other developing countries. Furthermore, if social distancing is not effective and/or is not sustained for long enough, the healthcare system may collapse, contributing to a greater tragedy.

Acknowledgments. The authors would like to thank the Brazilian research and development agencies for supporting this article.

Financial support. This work was supported by Coordenação de Aperfeiçoamento de Pessoal de Nível Superior (CAPES), by Brazilian National Council for Scientific and Technological Development (CNPq), and by Fundação de Amparo à Pesquisa do Estado de Minas Gerais (FAPEMIG). This letter was based on observations and reflections about the COVID-19 pandemic during studies supported by the funding agencies.

Conflicts of interest. All authors report no conflicts of interest related to this work.

\section{References}

1. Taghrir MH, Akbarialiabad H, Ahmadi Marzaleh M. Efficacy of mass quarantine as leverage of health system governance during COVID-19 outbreak: a mini policy review. Arch Iran Med 2020;23:265-267.

2. Parmet WE, Sinha MS. The law and limits of quarantine. $N$ Engl J Med 2020;382(15):e28.

3. Medidas Não Farmacológicas [in Italian]. Ministério da Saúde website. https://coronavirus.saude.gov.br/. Published 2020. Accessed April 27, 2020.

4. Advice on the use of masks the community, during homecare and in healthcare settings in the context of the novel coronavirus (2019-nCoV). Outbreak Interim Guidance. World Health Organization website. https://www.who. int/publications-detail/ Published 2020. Accessed April 27, 2020.

5. Cowling BJ, Ali ST, Ng TWY, et al. Impact assessment of non-pharmaceutical interventions against coronavirus disease 2019 and influenza in Hong Kong: an observational study. Lancet Public Health 2020; pii: S2468-2667(20)30090-6.

\title{
Double masking: Does science coincide with common sense?
}

\author{
Jeffrey T. Mueller $\mathrm{MD}^{1}$ (1), Soroor Karimi $\mathrm{PhD}^{2}$, Karl A. Poterack $\mathrm{MD}^{1}$, Maria Teresa A. Seville $\mathrm{MD}^{3}$ and \\ Steven M. Tipton $\mathrm{PhD}^{2}$ \\ ${ }^{1}$ Department of Anesthesiology, Mayo Clinic College of Medicine and Science, Phoenix, Arizona, ${ }^{2}$ Department of Mechanical Engineering, University of Tulsa, \\ Tulsa, Oklahoma and ${ }^{3}$ Division of Infectious Diseases, Mayo Clinic College of Medicine and Science, Phoenix, Arizona
}

Author for correspondence: Jeffrey T. Mueller, E-mail: mueller.jeff@mayo.edu

Cite this article: Mueller JT, et al. (2022). Double masking: Does science coincide with common sense?. Infection Control \& Hospital Epidemiology, 43: 954-955, https://doi.org/ $10.1017 /$ ice.2021.155
To the Editor-The importance of nonpharmaceutical interventions in preventing the spread of severe acute respiratory syndrome 